NASA/TM-2000-210216

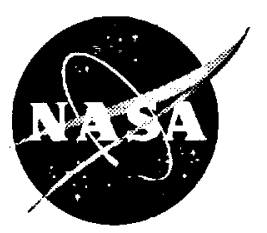

Fabrication of Fiber-Reinforced

Celsian Matrix Composites

Narottam P. Bansal

Glenn Research Center, Cleveland, Ohio

John A. Setlock

Case Western Reserve University, Cleveland, Ohio 
The NASA STI Program Office ... in Profile

Since its founding, NASA has been dedicated to the advancement of aeronautics and space science. The NASA Scientific and Technical Information (STI) Program Office plays a key part in helping NASA maintain this important role.

The NASA STI Program Office is operated by Langley Research Center, the Lead Center for NASA's scientific and technical information. The NASA STI Program Office provides access to the NASA STI Database, the largest collection of aeronautical and space science STI in the world. The Program Office is also NASA's institutional mechanism for disseminating the results of its research and development activities. These results are published by NASA in the NASA STI Report Series, which includes the following report types:

- TECHNICAL PUBLICATION. Reports of completed research or a major significant phase of research that present the results of NASA programs and include extensive data or theoretical analysis. Includes compilations of significant scientific and technical data and information deemed to be of continuing reference value. NASA's counterpart of peerreviewed formal professional papers but has less stringent limitations on manuscript length and extent of graphic presentations.

- TECHNICAL MEMORANDUM. Scientific and technical findings that are preliminary or of specialized interest, e.g., quick release reports, working papers, and bibliographies that contain minimal annotation. Does not contain extensive analysis.

- CONTRACTOR REPORT. Scientific and technical findings by NASA-sponsored contractors and grantees.
- CONFERENCE PUBLICATION. Collected papers from scientific and technical conferences, symposia, seminars, or other meetings sponsored or cosponsored by NASA.

- SPECIAL PUBLICATION. Scientific, technical, or historical information from NASA programs, projects, and missions, often concerned with subjects having substantial public interest.

- TECHNICAL TRANSLATION. Englishlanguage translations of foreign scientific and technical material pertinent to NASA's mission.

Specialized services that complement the STI Program Office's diverse offerings include creating custom thesauri, building customized data bases, organizing and publishing research results ... even providing videos.

For more information about the NASA STI Program Office, see the following:

- Access the NASA STI Program Home Page at http://wwww.sti.nasa.gov

- E-mail your question via the Internet to help@sti.nasa.gov

- Fax your question to the NASA Access Help Desk at (301) 621-0134

- Telephone the NASA Access Help Desk at (301) 621-0390

- Write to: NASA Access Help Desk NASA Center for AeroSpace Information 7121 Standard Drive Hanover, MD 21076 
NASA/TM-2000-210216

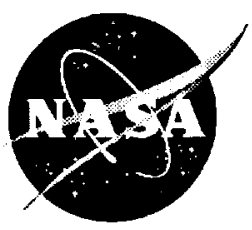

\section{Fabrication of Fiber-Reinforced Celsian Matrix Composites}

Narottam P. Bansal

Glenn Research Center, Cleveland, Ohio

John A. Setlock

Case Western Reserve University, Cleveland, Ohio

\section{Prepared for the}

"Processing of Fibers and Composites" Conference

Castelvecchio Pascoli, Italy, May 21-26, 2000

sponsored by the United Engineering Foundation, New York

National Aeronautics and

Space Administration

Glenn Research Center 


\section{Acknowledgments}

Thanks are due to Rob Dickerson, Terry Kacik, Ron Phillips and Ralph Garlick for technical assistance during this research.

Trade names or manufacturers' names are used in this report for identification only. This usage does not constitute an official endorsement, either expressed or implied, by the National Aeronautics and Space Administration.

Available from

NASA Center for Aerospace Information 7121 Standard Drive

Hanover, MD 21076

Price Code: A03
National Technical Information Service 5285 Port Royal Road Springfield, VA 22100 Price Code: A03 


\title{
FABRICATION OF FIBER-REINFORCED CELSIAN MATRIX COMPOSITES
}

\author{
Narottam P. Bansal \\ National Aeronautics and Space Administration \\ Glenn Research Center \\ Cleveland, Ohio 44135 \\ John A. Setlock \\ Department of Materials Science and Engineering \\ Case Western Reserve University \\ Cleveland, Ohio 44106
}

\section{SUMMARY}

A method has been developed for the fabrication of small diameter, multifilament tow fiber reinforced ceramic matrix composites. Its application has been successfully demonstrated for the Hi-Nicalon/celsian system. Strong and tough celsian matrix composites, reinforced with $\mathrm{BN} / \mathrm{SiC}$-coated $\mathrm{Hi}$-Nicalon fibers, have been fabricated by infiltrating the fiber tows with the matrix slurry, winding the tows on a drum, cutting and stacking of the prepreg tapes in the desired orientation, and hot pressing. The monoclinic celsian phase in the matrix was produced in situ, during hot pressing, from the $0.75 \mathrm{BaO}-0.25 \mathrm{SrO}-\mathrm{Al}_{2} \mathrm{O}_{3}-2 \mathrm{SiO}_{2}$ mixed precursor synthesized by solid state reaction from metal oxides. Hot pressing resulted in almost fully dense fiber-reinforced composites. The unidirectional composites having $\sim 42$ vol \% of fibers exhibited graceful failure with extensive fiber pullout in three-point bend tests at room temperature. Values of yield stress and strain were $435 \pm 35 \mathrm{MPa}$ and $0.27 \pm 0.01$ percent, respectively, and ultimate strengths of $900 \pm 60 \mathrm{MPa}$ were observed. The Young's modulus of the composites was measured to be $165 \pm 5 \mathrm{GPa}$.

\section{INTRODUCTION}

Monoclinic celsian $\mathrm{BaAl}_{2} \mathrm{Si}_{2} \mathrm{O}_{8}$ (BAS) and $\mathrm{SrAl}_{2} \mathrm{Si}_{2} \mathrm{O}_{8}$ (SAS) are refractory materials having melting points higher than $1700^{\circ} \mathrm{C}$. These materials are resistant to oxidation and reduction and also show reasonably good resistance to alkali attack. These materials are phase stable up to $\sim 1600^{\circ} \mathrm{C}$ and chemically compatible with alumina, mullite and silicon nitride (in inert or nitrogen atmospheres) at elevated temperatures. They show low values of dielectric constant and loss tangent which make them promising materials for electromagnetic windows or radome applications (ref. 1) at high temperatures, packaging for microelectronics, high voltage condensers and other electric insulating products. Celsian is also useful as an environmental barrier coating for $\mathrm{SiC}_{\rho} / \mathrm{SiC}$ composites and protects against the loss of silica as volatile silicon hydroxide species in the combustion products in turbine engines at elevated temperatures (ref. 2). Celsian is also being investigated as a matrix material for fiber-reinforced composites (refs. 3 to 6) for high temperature structural applications in hot sections of turbine engines.

BAS exists in three different polymorphs, the monoclinic, hexagonal, and orthorhombic phases. The monoclinic phase, commonly known as celsian, is the naturally occurring phase. The hexagonal phase, also known as hexacelsian, and the orthorhombic phase are found only in synthetic products. The hexacelsian phase is thermodynamically stable at temperatures between $1590^{\circ} \mathrm{C}$ and the melting point whereas the celsian phase is stable at temperatures below $1590^{\circ} \mathrm{C}$. However, hexacelsian can exist as a metastable phase at all temperatures from $1590^{\circ} \mathrm{C}$ to room temperature. At $\sim 300^{\circ} \mathrm{C}$, hexacelsian undergoes a rapid, reversible structural transformation (ref. 7) into the orthorhombic form, accompanied by a large volume change of $\sim 3$ percent. Thus, hexacelsian is an undesirable phase.

In both the BAS and SAS systems, hexacelsian is always the first phase to form. However, on heat treatment at $\sim 1200^{\circ} \mathrm{C}$ or higher temperatures, its transformation into the monoclinic phase is very sluggish in BAS (ref. 8) and very rapid in SAS (ref. 9). It is known that doping of BAS with SAS accelerates the hexacelsian to monoclinic celsian transformation (ref. 10). Fortunately, BAS and SAS form solid solutions in the entire composition range (refs. 1 and 10). The starting composition of $0.75 \mathrm{BaO}-0.25 \mathrm{SrO}-\mathrm{Al}_{2} \mathrm{O}_{3}-2 \mathrm{SiO}_{2}$ (BSAS) was used for the synthesis of monoclinic celsian in the present study. 
Processing and properties of celsian glass-ceramic matrix composites reinforced with large diameter CVD SiC SCS-6 monofilaments (refs. 3 to 6) and the multifilament small diameter Nicalon (ref. 11) and HPZ (ref. 12) fibers have been described earlier. The objective of this study was to develop the fabrication of small diameter, multifilament tow fiber-reinforced celsian matrix composites. Microstructures of the resulting FRCs were characterized and room temperature mechanical properties were measured. Strong, tough, and almost fully dense composites reinforced with $\mathrm{BN} / \mathrm{SiC}$-coated, Hi-Nicalon fibers have been obtained.

\section{MATERIALS AND EXPERIMENTAL PROCEDURE}

The matrix of $0.75 \mathrm{BaO}-0.25 \mathrm{SrO}-\mathrm{Al}_{2} \mathrm{O}_{3}-2 \mathrm{SiO}_{2}$ (BSAS) composition was synthesized by a solid-state reaction method (ref. 13). The starting materials used were $\mathrm{BaCO}_{3}$ (Alfa Products), $\mathrm{SrCO}_{3}$ (Alfa Products), $\mathrm{Al}_{2} \mathrm{O}_{3}$ (Baikowski International Corp., high purity $\mathrm{CR} 30$ ), and $\mathrm{SiO}_{2}$ (Cerac Inc., 99.9 percent purity, $\mathbf{- 3 2 5}$ mesh) powders. Appropriate quantities of various powders were slurry mixed in acetone and ball milled for $\sim 24 \mathrm{hr}$ using alumina milling media. Acetone was then evaporated and a part of the mixture was subjected to thermogravimetric analysis (TGA) in air. The oxide mixed powder was calcined at $\sim 900$ to $920^{\circ} \mathrm{C}$ for decomposition of the carbonates into oxides, followed by cooling to room temperature and grinding. A small part of the calcined powder was loaded into a graphite die and hot pressed at $1300^{\circ} \mathrm{C}$ for 2 to $3 \mathrm{hr}$ under $27.5 \mathrm{MPa}$ (4 ksi) pressure.

Polymer derived Hi-Nicalon fiber tows (1800 denier, 500 filaments/tow) with low oxygen content produced by Nippon Carbon Co. were used as the reinforcement. These fibers have an average diameter of $\sim 14 \mathrm{~mm}$; a reported (refs. 14 and 15 ) chemical composition (wt \%) of $62.4 \% \mathrm{Si}, 37.1 \% \mathrm{C}$, and $0.5 \% \mathrm{O}$; and $\mathrm{C} / \mathrm{Si}$ atomic ratio of $\sim 1.39$. The $\mathrm{Hi}$-Nicalon fibers mainly consist of $\mathrm{SiC}$ microcrystals with an average grain size of $4 \mathrm{~nm}$ and amorphous carbon. These fibers have a density of $2.7 \mathrm{~g} / \mathrm{cm}^{3}$, room temperature tensile strength of $\sim 2.8 \mathrm{GPa}$, elastic modulus of $270 \mathrm{GPa}$, and an average coefficient of thermal expansion of $3.5 \times 10^{-6} /{ }^{\circ} \mathrm{C}$ from room temperature to $500^{\circ} \mathrm{C}$. Hi-Nicalon fibers having a dual surface layer of $\mathrm{BN}$ overcoated with $\mathrm{SiC}$ were used in the present study. The fiber coatings were applied by a commercial vendor using a continuous chemical vapor deposition (CVD) reactor. The BN coating was deposited at $\sim 1000^{\circ} \mathrm{C}$ utilizing a proprietary precursor and was amorphous to partly turbostratic in nature. A thin overcoating of $\mathrm{SiC}$ was also deposited by $\mathrm{CVD}$ onto the $\mathrm{BN}$-coated fibers. The $\mathrm{SiC}$ layer was crystalline. The nominal coating thicknesses were $0.4 \mu \mathrm{m}$ for $\mathrm{BN}$ and $0.3 \mu \mathrm{m}$ for $\mathrm{SiC}$. The $\mathrm{BN}$ interfacial layer acts as a weak, crack-deflecting phase, while the SiC overcoat acts as a barrier to diffusion of boron from $\mathrm{BN}$ into the oxide matrix and also prevents diffusion of matrix elements into the fiber.

A sketch of the set-up used for infiltration of the matrix slurry into the fiber tows is shown in figure 1 . This is similar to the set-up reported earlier by Prewo (ref. 16). BSAS powder that had been calcined at 900 to $920^{\circ} \mathrm{C}$ for 20 to $24 \mathrm{hr}$ was made into a slurry by dispersing it in methyl ethyl ketone along with organic additives as binder, surfactant, deflocculant and plasticizer followed by ball milling. Tows of BN/SiC-coated Hi-Nicalon fibers were spread using rollers and coated with the matrix precursor by passing through the slurry. Excess slurry was squeezed out of the fiber tow before winding at $0.977 \mathrm{~mm}$ tow spacing ( 26 fiber tows/in.) on a rotating drum. After drying, the prepreg tape was cut to size. Unidirectional fiber-reinforced composites were prepared by tape lay up (12 plies) followed by warm pressing at $\sim 150^{\circ} \mathrm{C}$ to form a "green" composite. The fugitive organics were slowly burned out of the sample in air at $\sim 500^{\circ} \mathrm{C}$, followed by hot pressing under vacuum in a graphite die. Mêe hot pressẹ fiber-reinforced composite panel was surface polished and sliced into test bars $(\sim 50.4 \times 6.4 \times 1.9 \mathrm{~mm})$ for mechanical testing.

Thermogravimetric analysis (TGA) of the calcination process was carried out at a heating rate of $5{ }^{\circ} \mathrm{C} / \mathrm{min}$ under flowing air ( $60 \mathrm{mV} / \mathrm{min})$ from room temperature to $1500^{\circ} \mathrm{C}$ using a Perkin-Elmer TGA-7 system which was interfaced with a computerized data acquisition and analysis system. X-ray diffraction (XRD) patterns were recorded at room temperature using a step scan procedure $\left(0.02^{\circ} / 2 \theta\right.$ step, time per step 0.5 or $\left.1 \mathrm{sec}\right)$ on a Philips ADP-3600 automated diffractometer equipped with a crystal monochromator employing $\mathrm{Cu} \mathrm{K}_{\alpha}$ radiation. Density was measured from dimensions and mass as well as by the Archimedes method. Microstructures of the polished cross-sections and fracture surfaces were observed in an optical microscope as well as in a JEOL JSM-840A scanning electron microscope (SEM). For transmission electron microscopy (TEM), thin foils of the composite samples were prepared by slicing, polishing, dimple grinding, and argon ion beam milling. A thin carbon coating was evaporated onto the TEM thin foils and the SEM specimens for electrical conductivity prior to analysis. The thin foils were examined in a Philips EM400T operating at $120 \mathrm{keV}$.X-ray elemental analyses on the TEM were acquired using a Kevex thin window energy dispersive spectrometer (EDS) and analyzer. Mechanical properties were determined from stress-strain curves recorded in three-point flexure using an Instron 4505 universal testing instrument at a crosshead speed of $1.27 \mathrm{~mm} / \mathrm{min}(0.05 \mathrm{in} . / \mathrm{min})$ and support span 


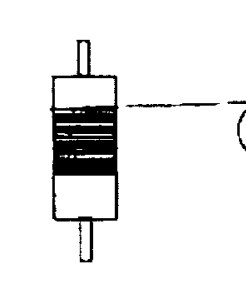

Fiber spool

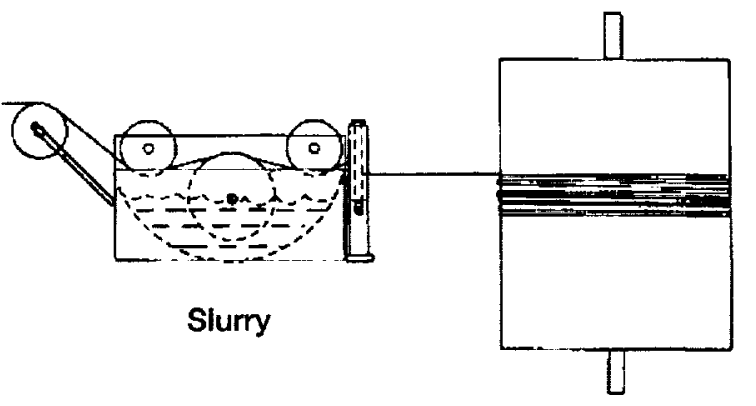

Take-up drum
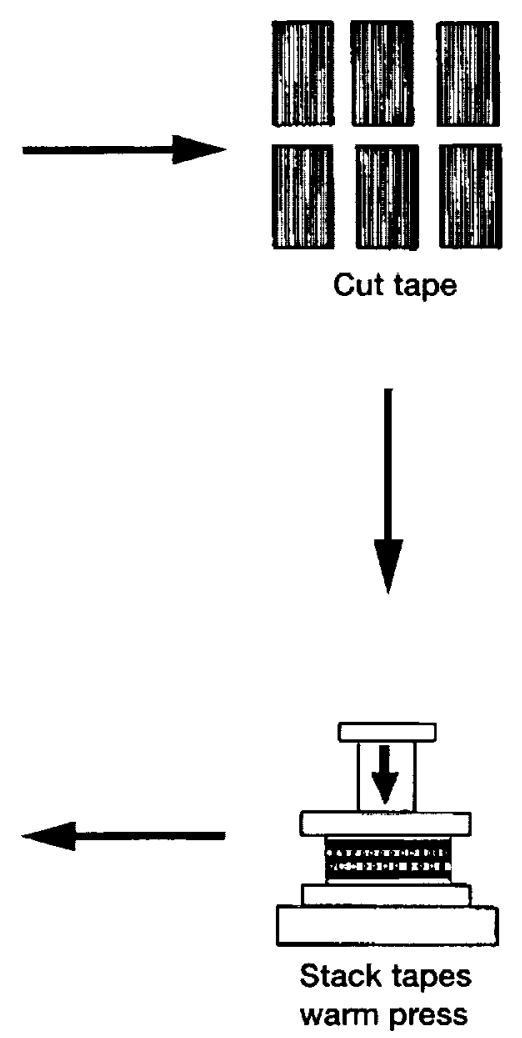

Figure 1.-Schematic of the set-up used for fabrication of small diameter multifilament fiber tow reinforced ceramic composites by matrix slurry infiltration and hot pressing.

(L) of $40 \mathrm{~mm}$. Strain gauges were glued to the tensile surfaces of the flexure test bars. Stress was calculated using beam theory. The yield stress was calculated from the stress-strain curves from the point where the curve deviates from linearity. Elastic modulus of the composite was determined from the linear portion of the stress-strain curve up to the yield point using linear interpolation.

\section{RESULTS AND DISCUSSION}

The TGA curve of the mixed BSAS powder consisting of metal carbonates and oxides is shown in figure 2. Minor weight loss near room temperature is due to evaporation of the residual moisture and acetone. A major event showing a large weight loss, due to the decomposition of barium and strontium carbonates into oxides, is observed between $\sim 750$ to $1000^{\circ} \mathrm{C}$. A calcination temperature of 900 to $920^{\circ} \mathrm{C}$ was chosen for decomposition of the carbonates. The mixed powder was calcined at this temperature for 20 to $24 \mathrm{hr}$ in air. TGA analysis of this calcined powder showed no further weight loss indicating complete decomposition of the metal carbonates during the calcination step.

The XRD pattern of the mixed powder, calcined at $\sim 915^{\circ} \mathrm{C}$ for $20 \mathrm{hr}$ in air, is presented in figure $3 . \mathrm{SiO}_{2}$ ( $\alpha$-quartz) and $\mathrm{BaAl}_{2} \mathrm{O}_{4}$ were the major phases present. Small amounts of $\mathrm{Ba}_{2} \mathrm{SiO}_{4}, \alpha-\mathrm{Al}_{2} \mathrm{O}_{3}$, and $\mathrm{Ba}_{2} \mathrm{Sr}_{2} \mathrm{Al}_{2} \mathrm{O}_{7}$ were also identified. Figure 4 shows the XRD pattern taken from the surface of a monolithic sample made by hot pressing the precalcined powder at $1300^{\circ} \mathrm{C}$ for $2 \mathrm{hr}$ under $27.5 \mathrm{MPa}(4 \mathrm{ksi})$. All the XRD peaks correspond to the monoclinic celsian phase with complete absence of the undesirable hexacelsian phase.

SEM micrographs showing the surface and the cross-sections of the BN/SiC coated Hi-Nicalon fibers are given in figure 5. The coatings on some of the fibers appear to be smooth and of uniform thickness whereas on other fibers the coating is very thick and granular. SEM micrographs taken from the polished cross-sections of the fibers are shown in figure 6. The double coating on the fiber surface is clearly visible. The dark layer is BN and the bright layer is SiC.

Some of the composite physical characteristics are given in table $\mathrm{I}$. The fiber volume fraction in the composites was calculated to be $\sim 42$ percent. From their densities, the composites appear to be almost fully dense. The XRD pattern taken 


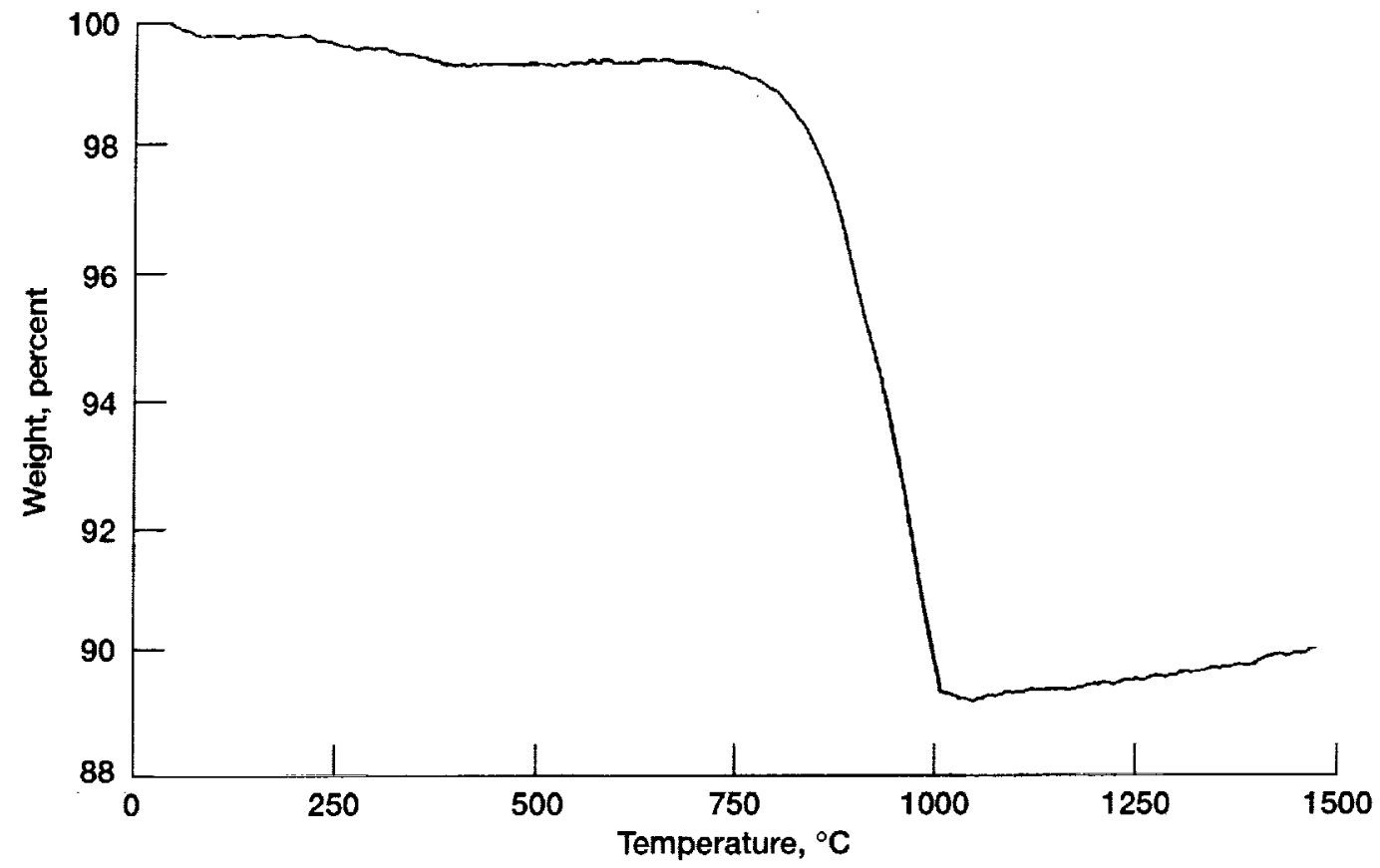

Figure 2.-TGA curve of $0.75 \mathrm{BaCO}_{3}-0.25 \mathrm{SrCO}_{3}-\mathrm{Al}_{2} \mathrm{O}_{3}-2 \mathrm{SiO}_{2}$ mixed powder at a heating rate of $5^{\circ} \mathrm{C} / \mathrm{min}$ in air.

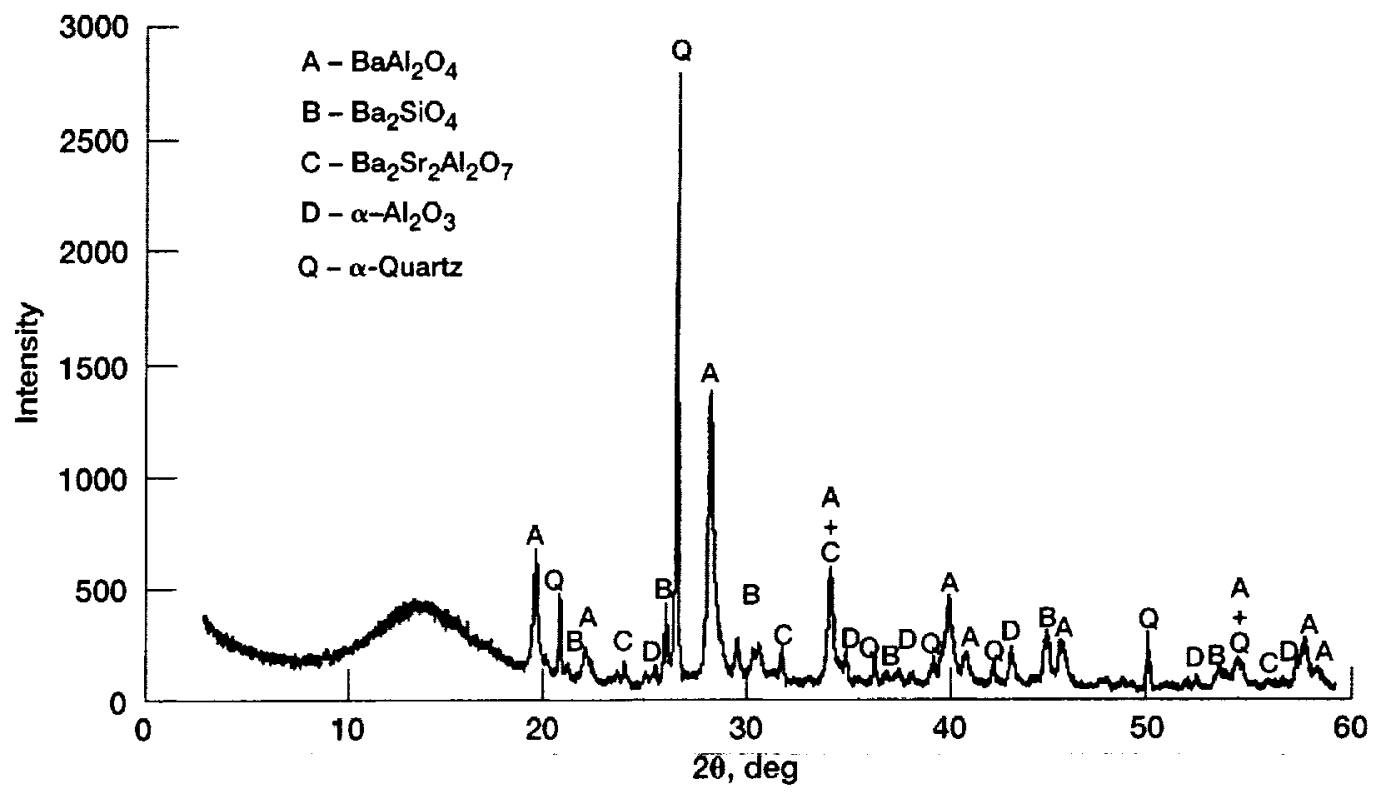

Figure 3.-Powder x-ray diffraction pattern of the mixed $0.75 \mathrm{BaCO}_{3}-0.25 \mathrm{SrCO}_{3}-\mathrm{Al}_{2} \mathrm{O}_{3}-2 \mathrm{SiO}_{2}$ powder after calcination at $915^{\circ} \mathrm{C}$ for $20 \mathrm{~h}$ in air. 


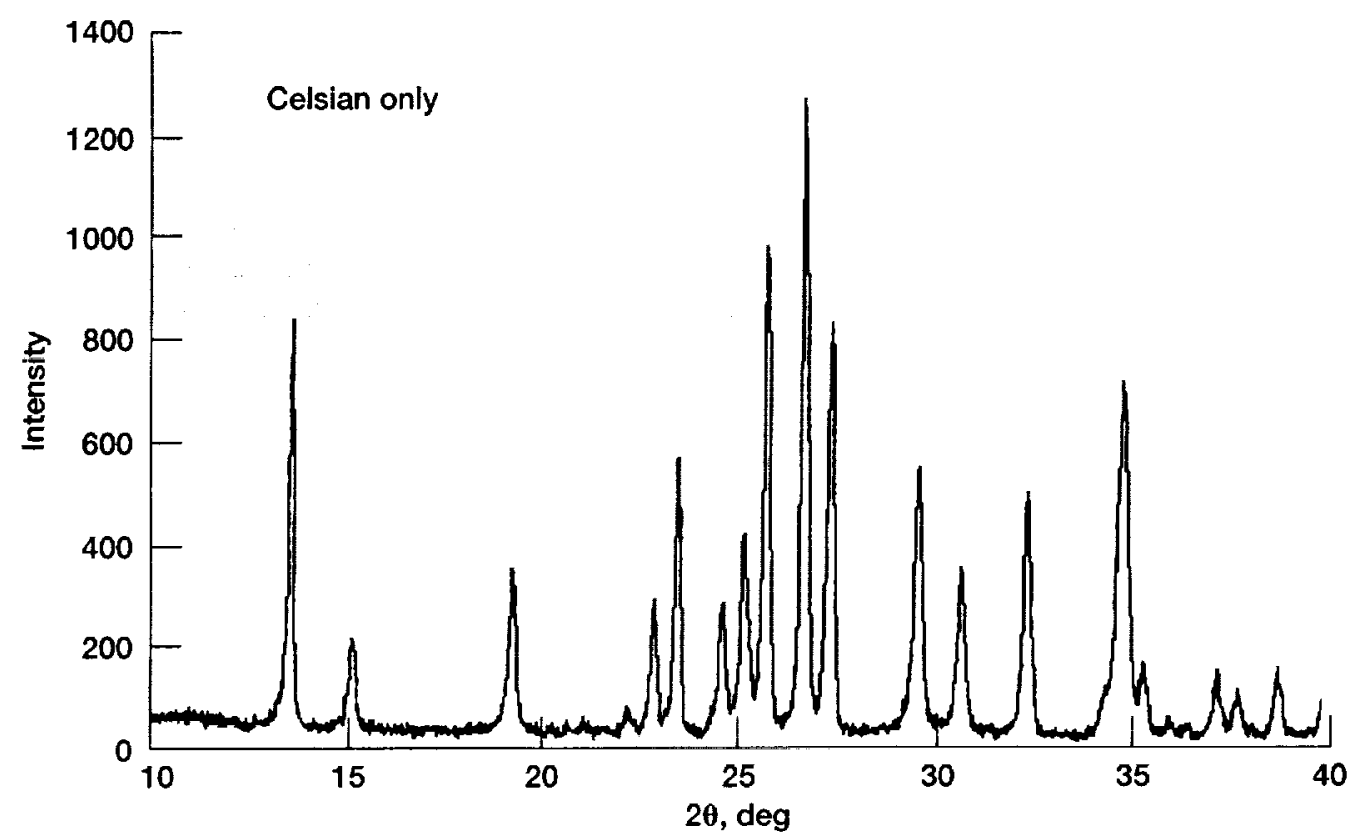

Figure 4.-X-ray diffraction spectra from the surface of $a \mathrm{Ba}_{0.75} \mathrm{Sr}_{0.25} \mathrm{Al}_{2} \mathrm{Si}_{2} \mathrm{O}_{8}$ plate hot pressed at $1300^{\circ} \mathrm{C}$ for $2 \mathrm{hr}$ at $27.6 \mathrm{MPa}$. All the diffraction peaks match with the monoclinic celsian phase.
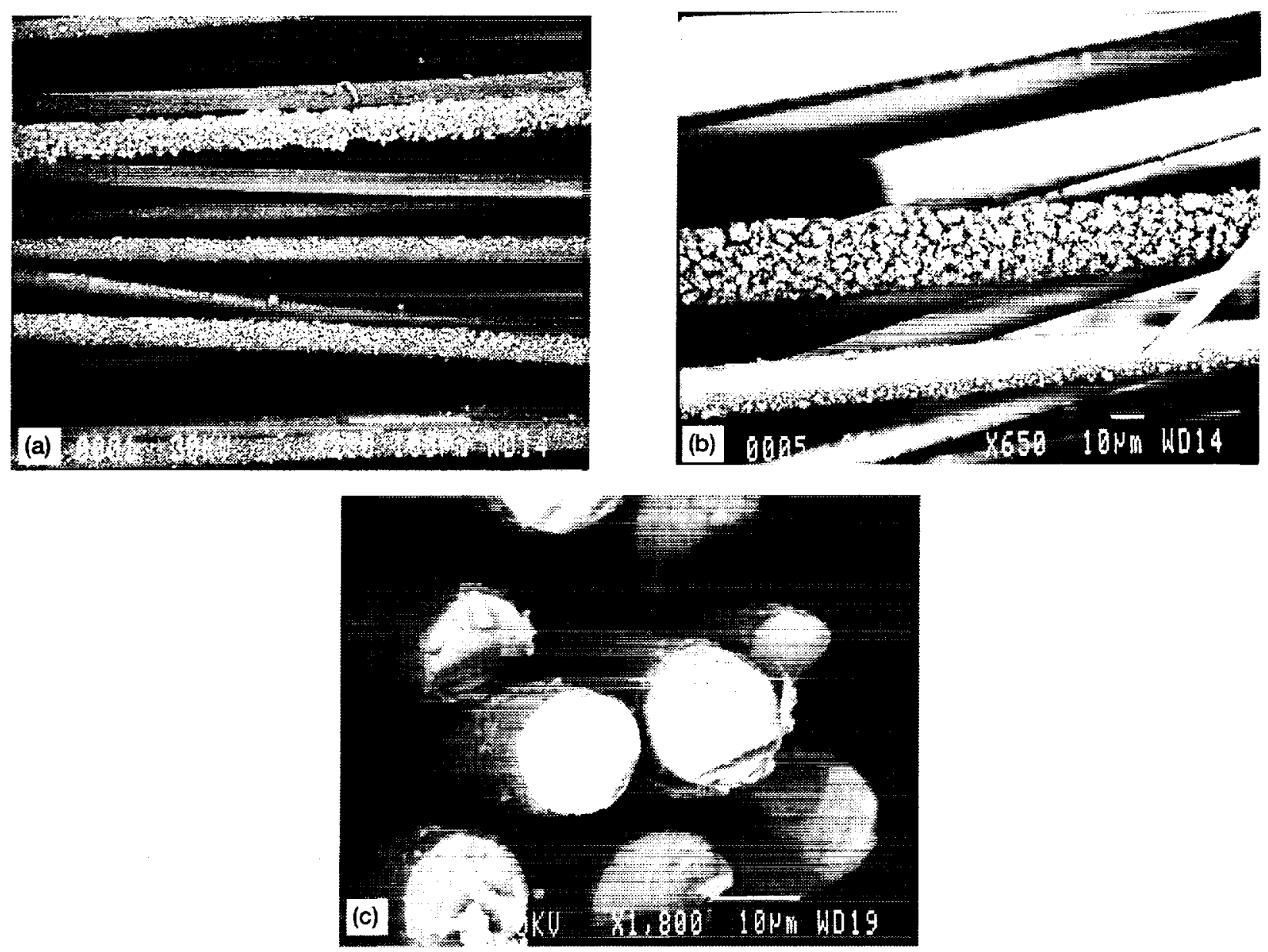

Figure 5.-SEM micrographs showing surface ( $a$ and $b$ ) and cross-section (c) of $B N / S i C$ coated Hi-Nicalon fibers. 

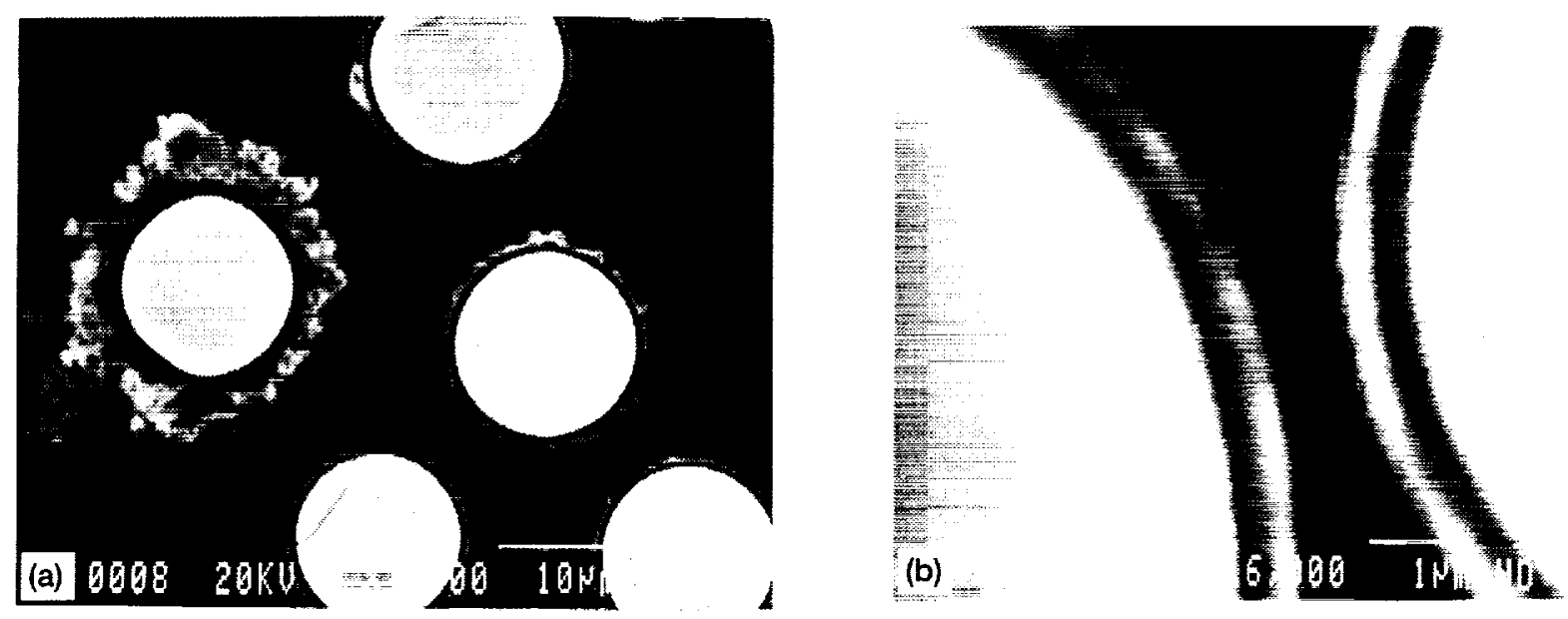

Figure 6.-SEM micrographs showing polished cross-section of Hi-Nicalon fibers with a duplex CVD BN/SiC coating. (a) Lower magnification. (b) Higher magnification.

TABLE I-HI-NICALON FIBER-REINFORCED Ba $\mathrm{B}_{035} \mathrm{Sr}_{0.35} \mathrm{Al}_{2} \mathrm{Si}_{2} \mathrm{O}_{8}$ CELSIAN COMPOSITES (UNIDIRECTIONAL; 12 PLIES)

\begin{tabular}{|c|c|c|c|c|l|}
\hline Sample number & \multicolumn{1}{|c|}{$\begin{array}{c}\text { Hot pressing } \\
\text { conditions }\end{array}$} & $\begin{array}{c}\text { Fiber } \\
\text { coating }\end{array}$ & $\begin{array}{c}\text { Fiber } \\
\text { content, } \\
\mathrm{V}_{\mathrm{f}}\end{array}$ & $\begin{array}{c}\text { Density, } \\
\left(\mathrm{g} / \mathrm{cm}^{3}\right)\end{array}$ & \multicolumn{1}{|c|}{ Phase from XRD } \\
\hline HI-NIC-BSAS-1-29-96 & Less aggressive & $\mathrm{BN} / \mathrm{SiC}$ & 0.42 & 3.05 & Monoclinic celsian \\
\hline HI-NIC-BSAS-1-31-96 & More aggressive & BN/SiC & 0.42 & 3.09 & Monoclinic celsian \\
\hline
\end{tabular}

from the polished surface of the hot pressed composite was similar to that shown in figure 3. Monoclinic celsian was the only crystalline phase present and the undesired hexacelsian phase was not detected from XRD. This implies that the desired, thermodynamically stable, monoclinic celsian phase is formed in situ, from the mixed oxides precursor, during hot pressing of the composite. Doping with SrO facilitates (refs. 9 and 10) the formation of monoclinic celsian in the matrix. In a recent study (ref. 17), a minor amount of hexacelsian phase has been detected in the matrix using Raman microspectroscopy.

SEM micrographs taken from the polished cross-section of the unidirectional hot pressed composite are shown in figure 7. Uniform fiber distribution and good matrix infiltration within the fiber tows is evident. Some of the filaments are of irregular shape rather than having circular cross-section. The manufacturer reports an average fiber diameter of $\sim 14 \mu \mathrm{m}$, but a large variation in the diameter of the filaments within a fiber tow can be seen. The BN/SiC surface coating has been detached from some of the fibers during metallography or composite processing. Debonding or loss of the fiber coating may lead to adverse reactions between the fibers and the oxide matrix at high temperature resulting in strong fibermatrix bonding.

TEM micrographs showing the fiber/matrix interface region of the Hi-Nicalon/BN/SiC/BSAS composite are presented in figure 8 . The BN coating consists of four distinct layers as seen in figure 8(a). From EDS analysis, the fiber/ $\mathrm{BN}$ interface was found to be rich in $\mathrm{C}$ along with the presence of $\mathrm{Si}$ and $\mathrm{O}$. The SiC overcoating was often found to be missing from the $\mathrm{BN} /$ matrix interface, but was intact in this particular case. A crack running along the fiber/BN interface may also be seen. The BN coating, when viewed via the TEM, did reveal an internal reaction. Some areas show no evidence of coarsening (fig. 8(a)) while others show varying amounts of reaction. Figure 8(b) shows coarsening of three $\mathrm{BN}$ layers, from outside in towards the fiber, during hot pressing of the composite. However, the fiber/BN interface and the inner BN layer remain unchanged. EDS spectra obtained from the coarsened region (fig. $9(\mathrm{a})$ ) show no obvious 

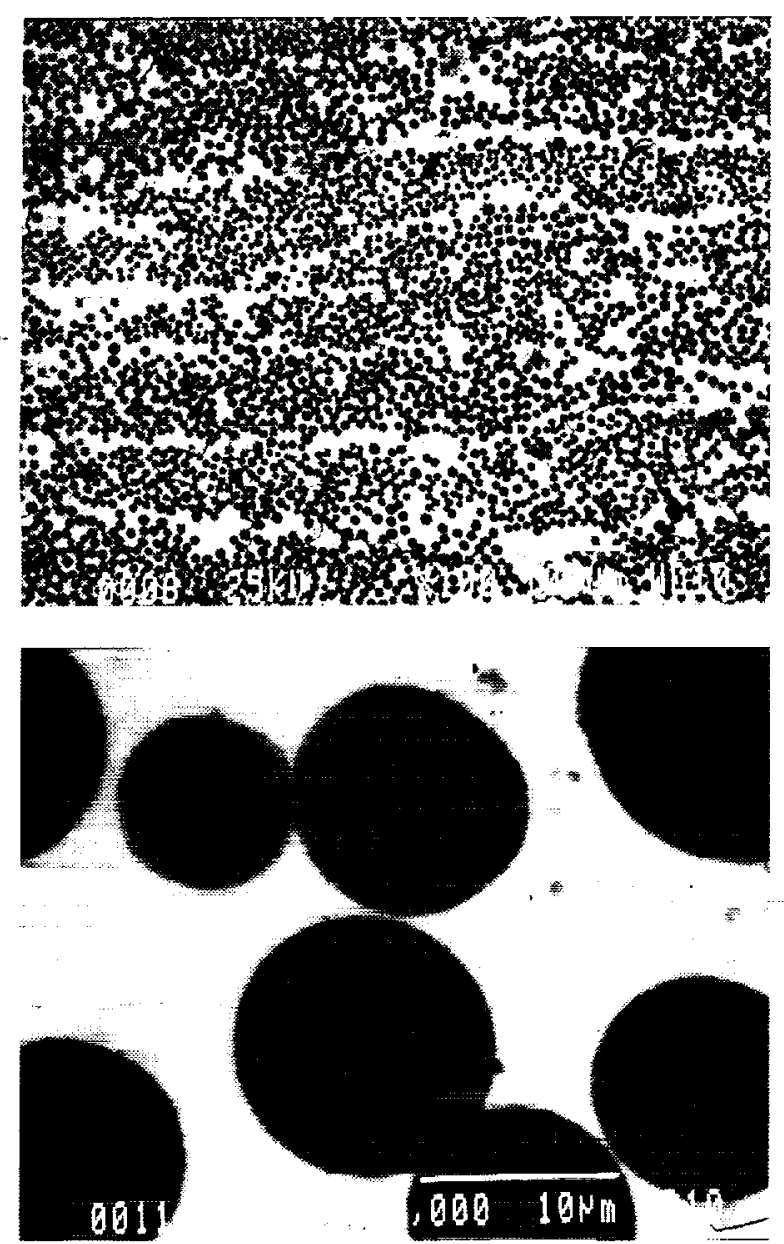
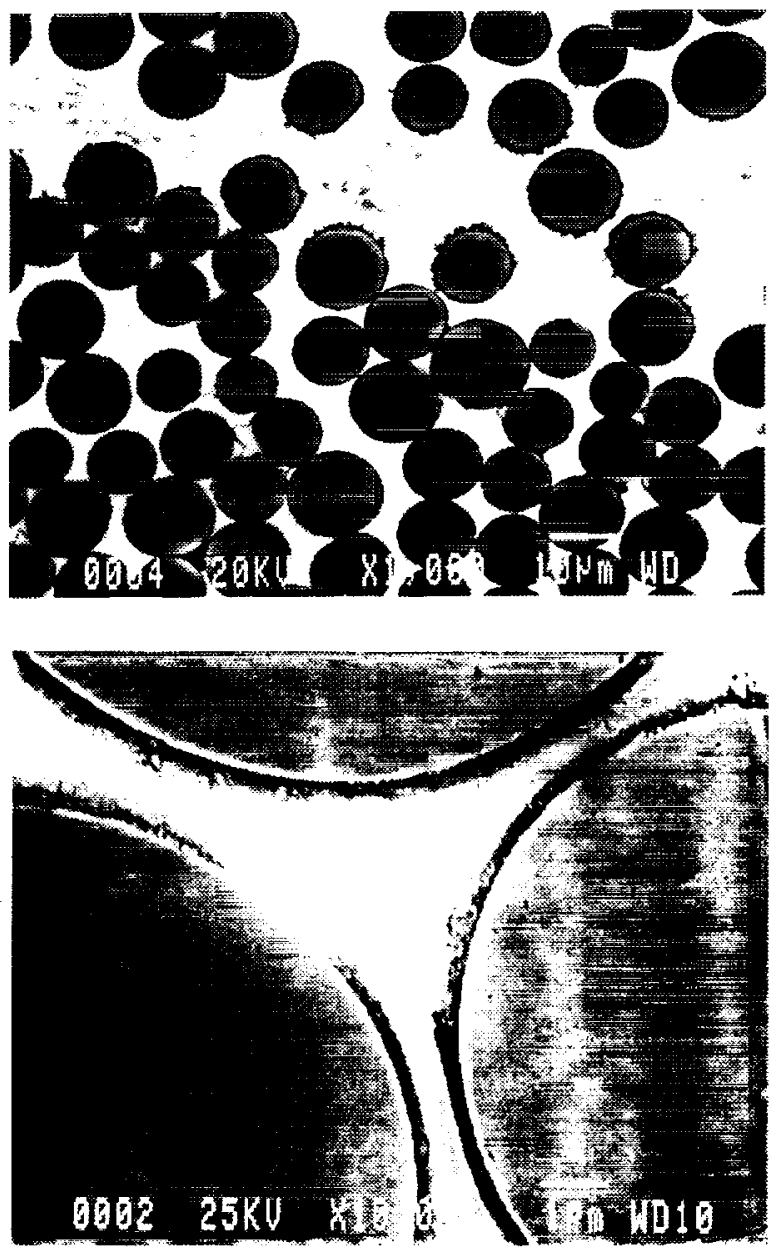

Figure 7.-SEM micrographs showing polished cross-section at different magnifications of a unidirectional Hi-Nicalon/BN/SiC/BSAS composite.
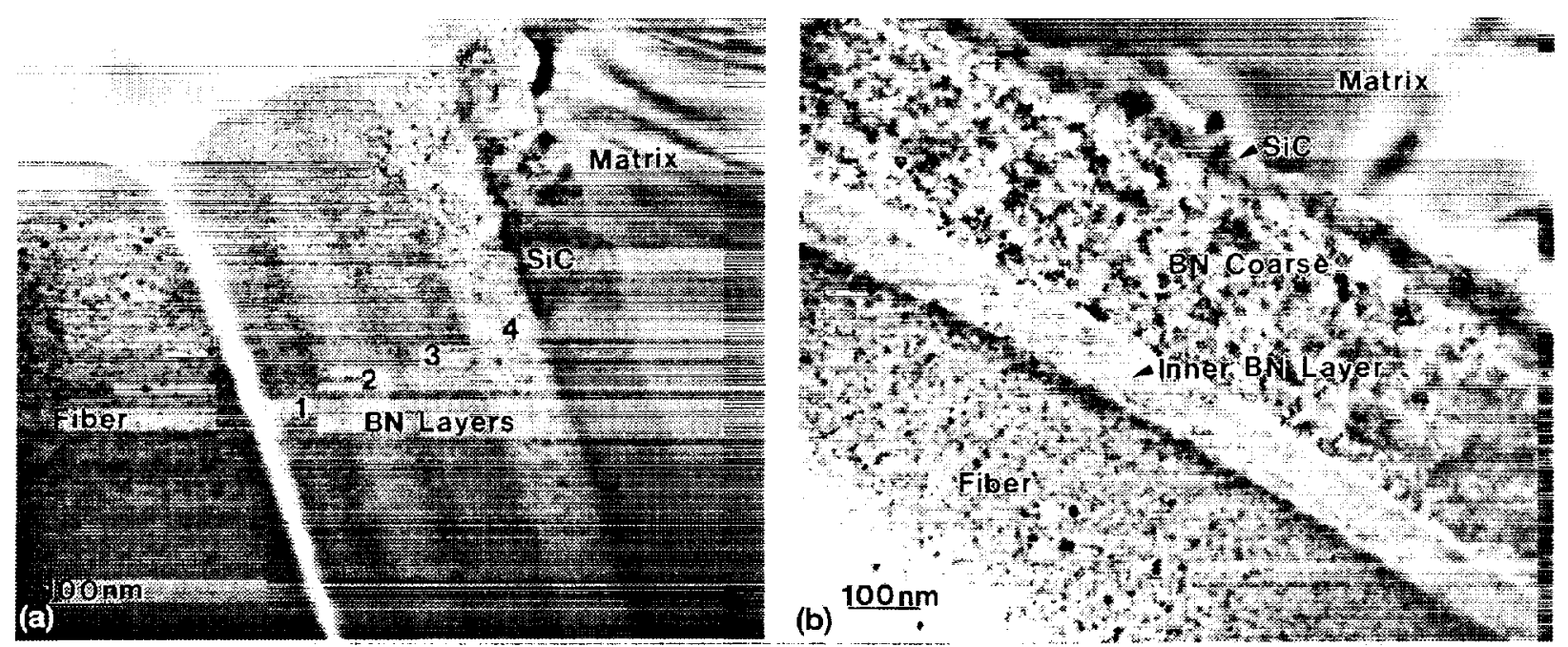

Figure 8.-TEM bright field image from cross-section of Hi-Nicalon/BN/SiC/BSAS composite showing

(a) multiple BN layers and (b) coarsening of the outer three BN layers. The inner BN and the SiC interface layers are unaffected. 
chemical changes in the various BN layers. Corresponding microdiffraction patterns (fig. 9 (b)) show coarsening to the point where individual diffraction spots are seen. It may be pointed out that reaction through all four BN layers or visible degradation of the fiber was never observed. The SiC layer remains apparently unaffected.

Typical stress-strain curves recorded in three-point flexure for the unidirectional BSAS matrix composites reinforced with BN/SiC-coated Hi-Nicalon fibers hot pressed at two different temperatures are shown in figure 10 . The fiber volume in the composites was $\sim 42$ percent. Both the composites show graceful failure. The values of yield stress, $\sigma_{y}$, yield strain, $\varepsilon_{\mathrm{y}}$, elastic modulus, E, ultimate strength. $\sigma_{\mathrm{u}}$, and ultimate strain. $\varepsilon_{\mathrm{u}}$, of the composites hot pressed at two different temperatures are given in table II. Values of yield stress of 400 to $470 \mathrm{MPa}$, ultimate strength of 850 to $960 \mathrm{MPa}$ and elastic modulus of 160 to $170 \mathrm{GPa}$ were observed. The measured elastic modulus is in good agreement with a value of $169 \mathrm{GPa}$, calculated from the rule-of-mixtures $\left(E_{c}=V_{m} E_{m}+V_{f} E_{f}\right.$ where $V$ is the volume fraction and the subscripts $c, m$, and $f$ refer to the composite, matrix, and fiber, respectively) using $E_{m}=96 \mathrm{GPa}$ (ref. 13) and $E_{\mathrm{f}}=270 \mathrm{GPa}$ (refs. 14 and 15). Values of yield strain and the ultimate strain are $\sim 0.26$ to 0.28 percent and $\sim 0.6$ to 0.8 percent, respectively.

SEM micrographs of fracture surfaces of the two composites, after the three-point flexure tests, are shown in figure 11. Extensive long lengths of fiber pullout are observed indicating toughening behavior. An SEM micrograph of the polished cross-section of a Hi-Nicalon/BN/SiC/BSAS composite, formed under more aggressive processing conditions and flexure tested at room temperature under ambient conditions, is presented in figure 12. Debonding at the fiber-matrix interface and crack deflection around the reinforcing fibers is observed indicating a tough composite. The results of this study clearly indicate that reinforcement of BSAS matrix with Hi-Nicalon fibers having a duplex BN/SiC coating results in a strong and tough composite.

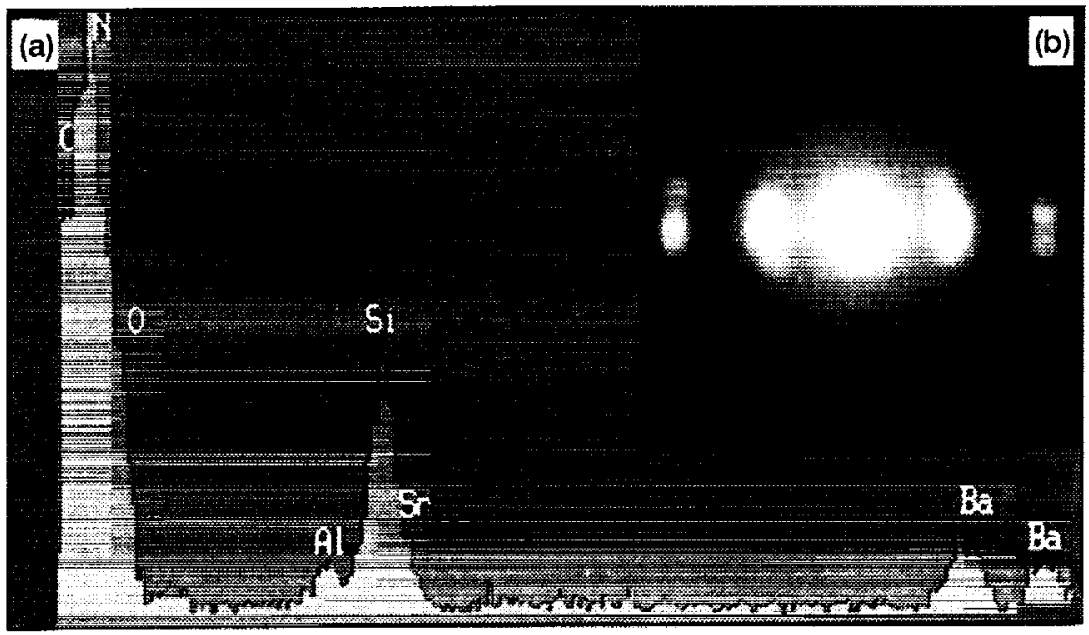

Figure 9.-EDS spectra from the coarsened $B N$ region (a) and the corresponding microdiffraction pattern (b).

TABLE II.-ROOM TEMPERATURE MECHANICAL PROPERTIES OF HI-NICALON FIBER-REINFORCED Ba $\mathrm{Ba}_{0.75} \mathrm{Sr}_{0.2} \mathrm{Al}_{2} \mathrm{Si}_{2} \mathrm{O}_{8} \mathrm{CELSLAN}$ COMPOSITES UNIDIRECTIONAL; 12 PLIES)

\begin{tabular}{|c|c|c|c|c|c|c|c|}
\hline Sample number & $\begin{array}{c}\text { Fiber } \\
\text { coating }\end{array}$ & $\begin{array}{c}\text { Fiber content, } \\
\mathrm{V}_{\mathrm{f}}\end{array}$ & $\begin{array}{c}\text { Elastic modulus, } \\
\mathrm{E}(\mathrm{GPa})\end{array}$ & $\begin{array}{c}\text { Yield stress, y } \\
(\mathrm{MPa})\end{array}$ & $\begin{array}{c}\text { Yield strain, } \\
(\%)\end{array}$ & $\begin{array}{c}\text { Ultimate } \\
\text { stress, } \\
(\mathrm{MPa})\end{array}$ & $\begin{array}{c}\text { Ultimate strain, } \\
\mathrm{u}(\%)\end{array}$ \\
\hline HI-NIC-BSAS-1-29-96 & $\mathrm{BN} / \mathrm{SiC}$ & 0.42 & 168 & 468 & 0.283 & 958 & 0.661 \\
& & 159 & 405 & 0.258 & 850 & 0.801 \\
\hline HI-NIC-BSAS-1-31-96 & BN/SiC & 0.42 & 170 & 436 & 0.264 & 862 & 0.583 \\
\hline
\end{tabular}

"Measured in 3-point flexure. 


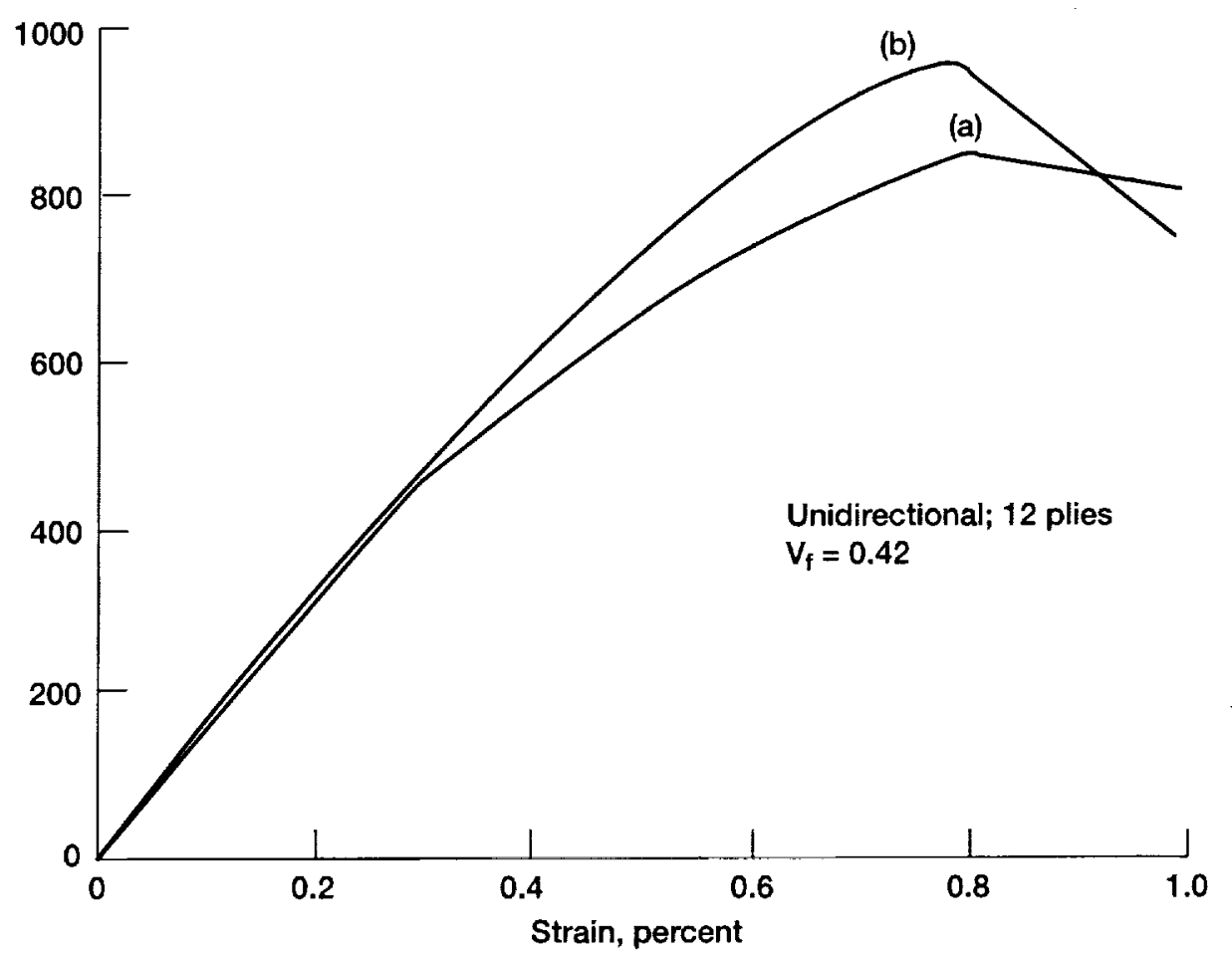

Figure 10.- Stress-strain curves recorded in 3-point flexture for unidirectional Hi-Nicalon/BN/SiC/BSAS composites hot pressed under (a) less and (b) more aggressive conditions.
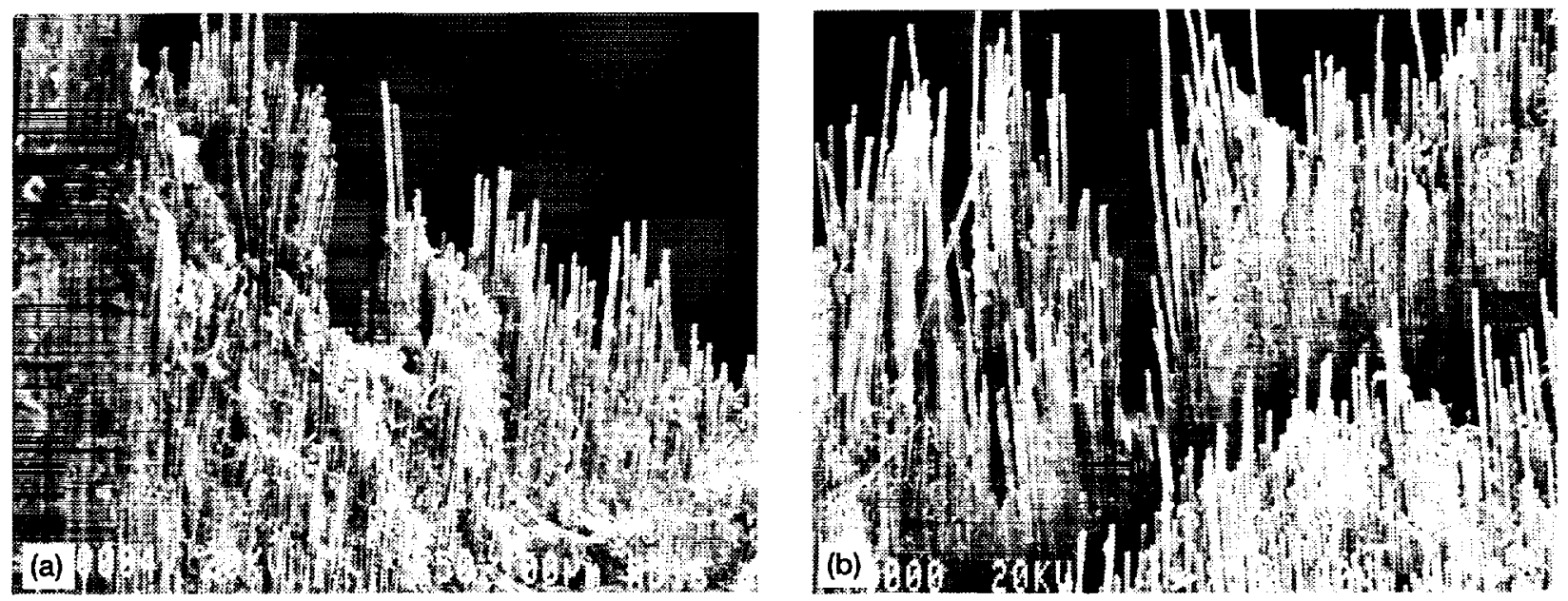

Figure 11.-SEM micrographs from the fracture surfaces of unidirectional Hi-Nicalon/BN/SiC/BSAS composites showing extensive fiber pullout; composites hot pressed under (a) less and (b) more aggressive conditions. 


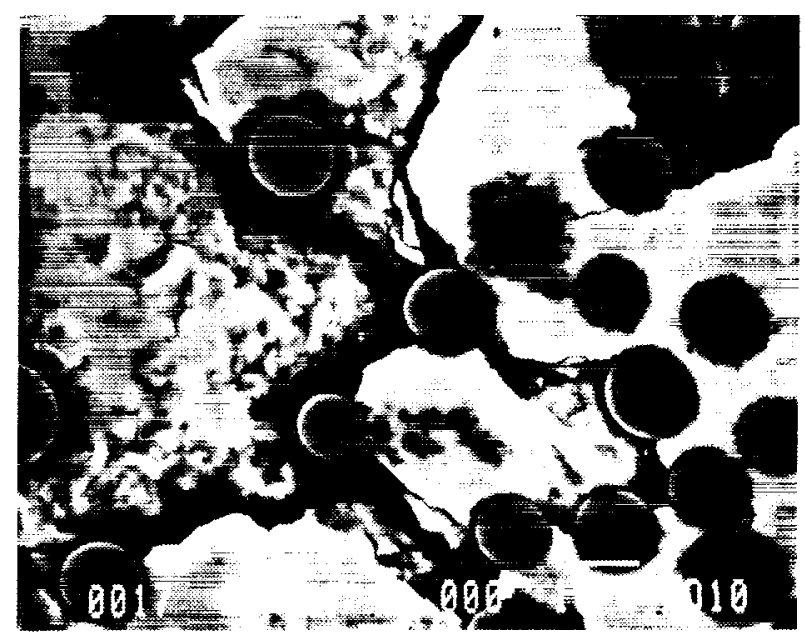

Figure 12.-SEM micrograph from the polished crosssection of a unidirectional Hi-Nicalon/BN/SiC/BSAS composite after the flexure test.

\section{SUMMARY OF RESULTS}

Hot pressing of mixed powder of $0.75 \mathrm{BaO}-0.25 \mathrm{SrO}-\mathrm{Al}_{2} \mathrm{O}_{3}-2 \mathrm{SiO}_{2}$ composition, obtained from calcination of metal carbonates and oxides, results in monoclinic celsian with complete absence of the undesirable hexacelsian phase. A method has been developed for the fabrication of small diameter multifilament tow fiber-reinforced ceramic matrix composites. BN/SiC-coated Hi-Nicalon fiber-reinforced monoclinic celsian composites have been produced by impregnation of the matrix slumy into the fiber tows, winding the tows on a drum, cutting and stacking of the prepreg tapes, and hot pressing. Strong, tough, and almost fully dense unidirectional composites having $-42 \mathrm{vol} \%$ of fibers were obtained. These composites exhibited graceful failure with extensive fiber pull out in a threepoint flexure test. The yield stress of $\sim 400$ to $470 \mathrm{MPa}$ and ultimate strength as high as $960 \mathrm{MPa}$ have been observed. The yield strain was $\sim 0.26$ to 0.28 percent. The Young's modulus of the composite was measured to be $\sim 165 \mathrm{GPa}$.

\section{CONCLUSIONS}

It may be concluded that reinforcement of the monoclinic celsian with BN/SiC-coated Hi-Nicalon fiber results in strong, tough, and almost fully dense composites.

\section{REFERENCES}

1. I.G. Talmy and D.A. Haught, Ceramics in the System $\mathrm{BaO} \cdot \mathrm{Al}_{2} \mathrm{O}_{3} \cdot 2 \mathrm{SiO}_{2}-\mathrm{SrO}_{\mathrm{Al}} \mathrm{Al}_{2} \mathrm{O}_{3} \cdot 2 \mathrm{SiO}_{2}$ for Advanced Radome Application, NSWC TE 89-162, Sept. 1989.

2. K.N. Lee, Current Status of Environmental Barrier Coatings for Si-Based Ceramics, Presented at the ICMCTF Conference, San Diego, CA, April 10-14, 2000.

3. N.P. Bansal, Ceramic Fiber Reinforced Glass-Ceramic Matrix Composite, U.S. Patent 5,214,004, May 25, 1993.

4. N.P. Bansal, Method of Producing a Silicon Carbide Fiber Reinforced Strontium Aluminosilicate GlassCeramic Matrix Composite, U.S. Patent 5,389,321, Feb. 14, 1995.

5. N.P. Bansal, CVD SiC Fiber-Reinforced Barium Aluminosilicate Glass-Ceramic Matrix Composites, Mater. Sci. Eng. A, 220, [1-2] pp. 129-139 (1996).

6. N.P. Bansal, Formation of Monoclinic Celsian in Silicon Carbide Fiber-Reinforced Barium Aluminosilicate GlassCeramic Matrix Composites, NASA TM-106993, August 1995.

7. Y. Takeuchi, A Detailed Investigation of the Structure of Hexagonal $\mathrm{BaAl}_{2} \mathrm{SiO}_{8}$ with Reference to its $\alpha-\beta$ Inversion, Min. J. Jpn., 2 [5] pp. 311-332 (1958). 
8. D. Bahat, Kinetic Study on the Hexacelsian-Celsian Phase Transformation, J. Mater. Sci., 5, pp. 805-810 (1970).

9. N.P. Bansal and C.H. Drummond III, Kinetics of Hexacelsian-to-Celsian Phase Transformation in $\mathrm{SrAl}_{2} \mathrm{Si}_{2} \mathrm{O}_{8}, J$. Am. Ceram. Soc., 76[5], pp. 1321-1324 (1993).

10. N.P. Bansal, M.J. Hyatt, and C.H. Drummond III, Crystallization and Properties of Sr-Ba Aluminosilicate GlassCeramic Matrices, Ceram. Eng. Sci. Proc., 12[7-8], pp. 122-21234 (1991).

11. N.P. Bansal, P. McCluskey, G. Linsey, D. Murphy, and G. Levan, Nicalon Fiber-Reinforced Celsian Glass-Ceramic Matrix Composites, Proceedings of Annual HITEMP Review, Cleveland, OH, October 23-25, 1995. NASA CP10178, Vol. III, pp. 41-I to 4I-14 (1995).

12. N.P. Bansal, Processing and Properties of HPZ Fiber-Reinforced Celsian Glass-Ceramic Matrix Composites, in preparation.

13. N.P. Bansal, Solid State Synthesis and Properties of Monoclinic Celsian, J. Mater. Sci., 33 [19], pp. 47I1-4715 (1998).

14. M. Takeda, J. Sakamoto, Y. Imai, H. Ichikawa, and T. Ishikawa, Properties of Stoichiometric Silicon Carbide Fiber Derived from Polycarbosilane, Ceram. Eng. Sci. Proc., 15 [4], pp. 133-141 (1994).

15. M. Takeda, J. Sakamoto, S. Saeki, Y. Imai, and H. Ichikawa, High Performance Silicon Carbide Fiber Hi-Nicalon for Ceramic matrix Composites, Ceram. Eng. Sci. Proc., 16 [4], pp. 37-44 (1995).

16. K.M. Prewo, Fiber-Reinforced Glasses and Glass-Ceramics, in Glasses and Glass-Ceramics, Edited by M.H. Lewis, Chapman and Hall, New York, 1989, pp. 336-368.

17. G. Gouadec, P. Colomban, and N.P. Bansal, Raman Study of Hi-Nicalon Fiber Reinforced Celsian Matrix Composites. Part 1: Distribution and Nanostructure of Different Phases, to be published. 
Public reporting burden for this collection of information is estimated to average 1 hour per response, including the time for revlewing instructions, searching existing data sources, gathering and maintaining the data needed, and completing and reviewing the collection of information. Send comments regarding this burden estimate or any other aspect of this collection of information, including suggestions for reducing this burden, to Washington Headquarters Services, Directorate for Information Operations and Reports. 1215 Jefferson Davis Highway, Suite 1204, Arlington, VA 22202-4302, and to the Office of Management and Budget, Paperwork Reduction Project (0704-0188), Washington, DC 20503.

\begin{tabular}{|l|l|l}
\hline 1. AGENCY USE ONLY (Leave blank) & $\begin{array}{c}\text { 2. REPOAT DATE } \\
\text { June } 2000\end{array}$ & $\begin{array}{c}\text { 3. REPORT TYPE AND DATES COVERED } \\
\text { Technical Memorandum }\end{array}$
\end{tabular}

\section{TITLE AND SUBTITLE}

5. FUNDING NUMBERS

Fabrication of Fiber-Reinforced Celsian Matrix Composites

6. AUTHOR(S)

Narottam P. Bansal and John A. Setlock

7. PERFORMING ORGANIZATION NAME(S) AND ADDRESS(ES)

National Aeronautics and Space Administration

John H. Glenn Research Center at Lewis Field

Cleveland, Ohio 44135-3191

9. SPONSORING/MONITORING AGENCY NAME(S) AND ADDRESS(ES)

National Aeronautics and Space Administration

Washington, DC 20546-0001
WU-523-31-13-00

8. PERFORMING ORGANIZATION REPORT NUMBER

E-12335

10. SPONSORING/MONITORING AGENCY REPORT NUMBER

NASA TM-2000-210216

11. SUPPLEMENTARY NOTES

Prepared for the "Processing of Fibers and Composites" Conference, Castelvecchio Pascoli, Italy, May 21-26, 2000; sponsored by the United Engineering Foundation, New York. Narottam P. Bansal, NASA Glenn Research Center and John A. Setlock, Department of Materials Science and Engineering, Case Western Reserve University, Cleveland, Ohio 44106. Responsible person, Narottam P. Bansal, organization code 5130, (216) 433-3855.

12a. DISTRIBUTION/AVAILABILITY STATEMENT

12b. DISTRIBUTION CODE

Unclassified - Unlimited

Subject Category: 24

Distribution: Nonstandard

This publication is available from the NASA Center for AeroSpace Information. (301) 621-0390.

13. ABSTRACT (Maximum 200 words)

A method has been developed for the fabrication of small diameter, multifilament tow fiber reinforced ceramic matrix composites. Its application has been successfully demonstrated for the Hi-Nicalon/celsian system. Strong and tough celsian matrix composites, reinforced with $\mathrm{BN} / \mathrm{SiC}$-coated Hi-Nicalon fibers, have been fabricated by infiltrating the fiber tows with the matrix slurry, winding the tows on a drum, cutting and stacking of the prepreg tapes in the desired orientation, and hot pressing. The monoclinic celsian phase in the matrix was produced in situ, during hot pressing, from the $0.75 \mathrm{BaO}-0.25 \mathrm{SrO}-\mathrm{Al}_{2} \mathrm{O}_{3}-2 \mathrm{SiO}_{2}$ mixed precursor synthesized by solid state reaction from metal oxides. Hot pressing resulted in almost fully dense fiber-reinforced composites. The unidirectional composites having $\sim 42 \mathrm{vol} \%$ of fibers exhibited graceful failure with extensive fiber pullout in three-point bend tests at room temperature. Values of yield stress and strain were $435 \pm 35 \mathrm{MPa}$ and $0.27 \pm 0.01$ percent, respectively, and ultimate strengths of $900 \pm 60 \mathrm{MPa}$ were observed. The Young's modulus of the composites was measured to be $165 \pm 5 \mathrm{GPa}$.

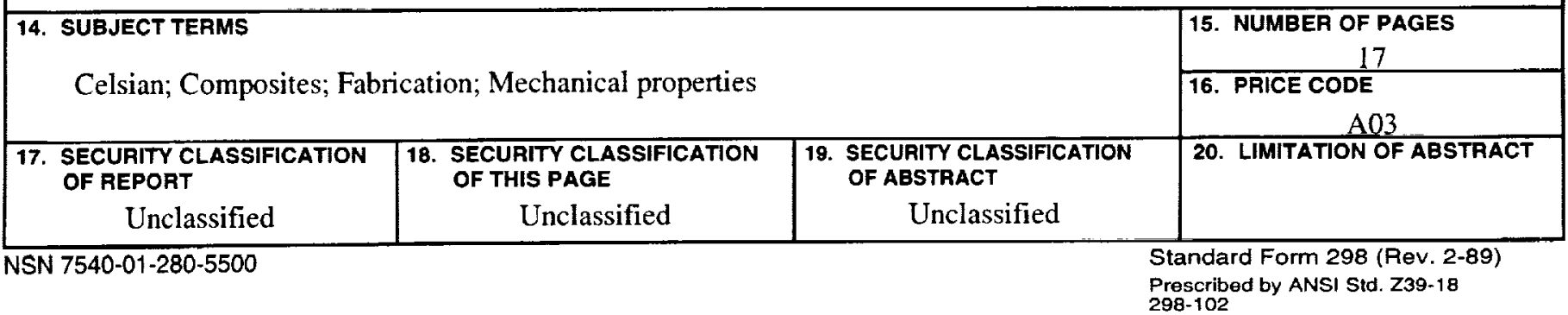

